\title{
FLOOD DAMAGE FUNCTIONS IN THE VRBAS RIVER BASIN
}

\author{
RADUŠKA CUPAĆ ${ }^{1}$, EDIN ZAHIROVIĆ ${ }^{2} \&$ VUJADIN BLAGOJEVIĆ 3 \\ ${ }^{1}$ United Nations Development Programme B\&H, Bosnia and Herzegovina \\ ${ }^{2}$ Centre for development and support Tuzla, Bosnia and Herzegovina \\ ${ }^{3}$ Institute for water management Bijeljina, Bosnia and Herzegovina
}

\begin{abstract}
The primary task of this research is the development of flood damage functions in order to demonstrate the level of damage caused to household assets and agriculture by floods in the Vrbas river basin in Bosnia and Herzegovina. Damage functions describe the connection between the flood depth and the value of flood-affected assets and potential damage. In the process of developing the function, information on representative buildings viewed from the perspective of civil engineering and electrical machinery, as well as representative building with its movables, were used. Results of the damage functions relate to synthetic damage that is not the result of registered damage in the past. It consists of the following steps: (1) selection of representative residential buildings and an assessment of their market value and the value of any movables, (2) determination of the characteristics of flood levels above ground level through hydrology and the use of hydraulic models, (3) expert assessment of the resulting damage in accordance with the specific flood levels in those buildings, and (4) determination of the value of the damage caused to the buildings taking into consideration the increase in damage in relation to the flood depth. The total agricultural flood damage in the basin was assessed as the result of the sum of losses in the floodplain based on the most represented crops. The total cost of the flood damage was obtained by multiplying the losses incurred because of the reduction in yields expressed in Euro/ha and based on the surface area of crops in the floodplain (ha). Damage functions were used to calculate the potential flood damage in the Vrbas river basin. The potential amount of damages calculated for households and agriculture was EUR 47 mil. It was in accordance with recorded actual flood damages from 2014 in the Vrbas river basin, so they can be used for future analyses.

Keywords: damage function, flood depth, potential damage, Vrbas river basin, household assets.
\end{abstract}

\section{INTRODUCTION}

Damage functions represent the relationship between the flood depth and the value of flood affected assets and potential damage. In the relevant literature, the main parameter for determining the damage value is the flood depth or more precisely the flood depth in the building. In addition to flood depth, the water speed of the flood wave, the duration of the flood, the seasonality or time of the flooding affect the amount of damage; however, these parameters are rarely included in the calculation of the amount of damage [1]. Two main approaches are distinguishable in the development of flood damage models: empirical approaches that use damage data collected after flood events and synthetic approaches that use damage data collected via "what if" questions. "What if" analyses estimate the level of damage expected in the case of a certain flood situations, namely "Which damage would you expect if the flood depth was $2 \mathrm{~m}$ above the building floor?" [2]. Penning-Rowsell et al. present examples for this approach [3]. Results of the damage functions addressed in this analysis are synthetic. They are not the result of registered damage in the past but the result of a process that comprised the following steps:

1. selection of representative residential buildings and an assessment of their value as well as the value of any movables in those buildings;

2. determination of the characteristics of flood levels above ground level through hydrology and the use of hydraulic models; 
3. expert assessment of the resulting damage caused to the representative buildings in accordance with the specific flood levels in those buildings;

4. determination of the value of the damage caused to the buildings taking into consideration the increase in damage in relation to the flood depth, in fact determining the damage function.

The synthetic damage functions addressed in this analysis are for projection purposes and relate mainly to future and consequent calculations in cost-benefit analysis and the analysis of asset insurance and the flood protection system. To select the representative residential buildings and estimate their value, telephone interviews were conducted covering all settlements within the Vrbas river basin exposed to flood risk. The Vrbas river basin is part of the Danube river basin. It is located in north western Bosnia and Herzegovina (BH) and covers an area of $6,386 \mathrm{~km}^{2}$. It is not usual to use site specific flood characteristics for developing the damage functions, but the reason for selecting only Vrbas river basin when creating the damage functions is the existence of relevant hydrology, hydraulic, socio-economic and other flood-related data for this river basin. For other basins in BH the data are not specified, particularly hydrology and hydraulic data which do not exist or their making is ongoing. All these data were generated during the project of flood risk mitigation in the Vrbas river basin implemented by the United Nations Development Programme (UNDP). The average value of the household assets was obtained through a phone assessment that covered 3,500 households more or less exposed to flood risk utilising a stratified random sample that took into consideration representation per the criteria urban and rural. The settlements were selected for strata and the average number of respondents per settlement was $5 \%$ of the total population in a given settlement. In addition to general questions, the interview included questions on residential and support buildings and their features.

Two types of data are used to calculate the flood damage curve for households (according to the principle of $\%$ assets value). The first, average value of household assets and the second related to the average damage on building and movables. Putting in ratio the damage on building (with or without movables) and average market value of household assets (with or without movables), the percentage of damage for household assets (with or without movables) is obtained for different flood levels. To calculate the first data, the average values of household assets, market value is used which takes into consideration the material of which the buildings are made, number of floors in building, location of building, connection of building with utility infrastructure, dimensions, year of construction and terms of building maintenance including the value of movables. Use of the market value of household assets reflects the actual differences in development level of certain municipalities within the assessed region. The following market values were considered in order to calculate the value of the household assets: the value of apartment/house, fence, heating system as well as significant electricity users, significant furniture, agricultural equipment, fodder stocks and livestock. This combined with the value of individual assets is how the average value of the assets per household per settlement is presented. To calculate the second data, the amount of damage on building and movables, the costs of bringing the building and associated movables into the initial condition are taken into consideration, especially rebuilding and replacement costs.

Flood hazard and flood risk maps developed for the Vrbas river basin were used to determine values in relation to the characteristic flood levels. The expert assessment of risk to representative buildings in line with the characteristic flood levels was conducted at representative residential buildings in the Vrbas river basin. The damage to these buildings was assessed in terms of civil engineering and electrical machinery based on flood depth 
water levels in buildings set at $0.5 \mathrm{~m}$, namely from $0.5-5 \mathrm{~m}$. Depending on the water depth in a building, the cost of the works required to return the building to function or its initial condition, in fact the rebuilding costs, were assessed.

In relation to the civil engineering aspect, the following types of work were considered: repair of outside fences, cleaning the well and repairing the hydro pack, emptying the septic tanks, drying the walls, removal of the existing internal and exterior joinery and the installation of new joinery, painting the walls and ceiling, removal of the existing wooden floor (parquet, ship floor) and the purchase and installation of new floor.

In relation to the electrical machinery aspect, the following types of works were considered: purchase of materials and electrical installation works; purchase of all materials for the installation of the main electrical box with all necessary measures of electrical protection and the space for the installation of the meter and counter and installation of the appropriate set including all necessary works as well as grounding works; purchase and installation of a single-phase two-tariff meter; purchase of the materials and balancing the potential for water installations; obtain the certificate and registration for electrical installation testing in house; repair the heating boiler; replacement of the main electronic board and internal ventilator in boilers and/or cleaning and replacement of damaged parts in individual stoves.

The cost of the reconstruction works required to repair the damage caused to a building was determined taking into consideration all of the above-mentioned types of works for all flood levels in buildings ranging from $0.5-5 \mathrm{~m}$. In this way, a unified damage function pertaining to representative buildings in the Vrbas river basin was established. The usual practice is to present the damage as a percentage of the total value of the building [4], [5]. This was done by comparing the average value of representative buildings in the Vrbas river basin in accordance with the equation below

$$
\% \text { damage }=\frac{\text { reconstruction costs }}{\text { total value of representative building }} .
$$

To determine the damage function in a representative building with movables, in addition to the reconstruction costs, the cost of replacing significant electrical appliances, furniture as well as agricultural equipment and other movables are included. In this case, the damage is presented as a percentage of the value of the total household assets in accordance with the equation below

$$
\% \text { damage }=\frac{\text { reconstruction costs }+ \text { replacement of movables }}{\text { total value of household assets }} .
$$

Since the average value of assets in household was determined for each of the 13 municipalities in the Vrbas river basin, 13 damage functions were established based on the value of the assets. All 13 damage functions were analysed per municipality leading to the conclusion that it is possible to establish three similar groups of municipalities to be presented with three damage functions. Grouping the municipalities in order to determine damage functions was done according to the household assets value criteria per municipalities/cities except for Banja Luka city. One damage function relates to the City of Banja Luka as it is business, administrative, academic and cultural centre and exceptionally urban area with over $60 \%$ of total population from the Vrbas river basin. Another damage function relates to the average value of household assets over 100,000 Bosnia and Herzegovina convertible mark - BAM (EUR 51,129) for the municipalities of Gradiška (156,035 BAM), Jajce (101,101 BAM), Kotor Varoš (128,895 BAM), Laktaši (124,236 BAM) and Srbac (119,434 BAM). Average value of household assets to 100,000 BAM (EUR 
$51,129)$ includes the municipalities which make the third damage function, such as: Bugojno municipality (average value of household assets 92,144 BAM), Čelinac (90,652 BAM), Donji Vakuf (73,386 BAM), Gornji Vakuf (85,257 BAM), Jezero (86,787 BAM), Šipovo (78,077 BAM) and Mrkonjić Grad (75,376 BAM). The value of household assets reflects the development level of municipalities and cities in $\mathrm{BH}$ frames.

\section{DAMAGE FUNCTION DEPENDING ON THE FLOOD DEPTH FOR A BUILDING}

Damage function depends on the flood depth in a representative building and this was obtained for buildings without movables based on the average value of representative buildings in the Vrbas river basin and the reconstruction costs for all flood levels in buildings (from $0.5-5 \mathrm{~m}$ ).

The average value of a representative building in the Vrbas river basin is BAM 94,415 (EUR 48,274) without movables. In line with the average value of representative buildings in the Vrbas river basin, the percentage value of damage obtained is as presented in Table 1 and Fig. 1.

Table 1: Reconstruction costs for representative buildings in the Vrbas river basin with the damage value set according to the flood level. (Source: Author.)

\begin{tabular}{|c|c|c|}
\hline $\begin{array}{c}\text { Water depth in } \\
\text { building }(\mathrm{x})\end{array}$ & Reconstruction costs & $\begin{array}{c}\% \text { damage value to building } \\
(\mathrm{x}) \text { (without movables) }\end{array}$ \\
\hline $0.5 \mathrm{~m}$ & 7,924 BAM (4,051 EUR) & $8.4 \%$ \\
\hline $1.0 \mathrm{~m}$ & 11,870 BAM (6,069 EUR) & $12.4 \%$ \\
\hline $1.5 \mathrm{~m}$ & 12,618 BAM (6,451 EUR) & $13.2 \%$ \\
\hline $2.0 \mathrm{~m}$ & 12,885 BAM (6,588 EUR) & $13.5 \%$ \\
\hline $2.5 \mathrm{~m}$ & 13,204 BAM (6,751 EUR) & $13.8 \%$ \\
\hline $3.0 \mathrm{~m}$ & 16,306 BAM (8,337 EUR) & $17.1 \%$ \\
\hline $3.5 \mathrm{~m}$ & 16,339 BAM (8,354 EUR) & $17.1 \%$ \\
\hline $4.0 \mathrm{~m}$ & 18,759 BAM (9,591 EUR) & $19.7 \%$ \\
\hline $4.5 \mathrm{~m}$ & 18,824 BAM (9,625 EUR) & $19.7 \%$ \\
\hline $5.0 \mathrm{~m}$ & 19,000 BAM (9,715 EUR) & $19.9 \%$ \\
\hline
\end{tabular}

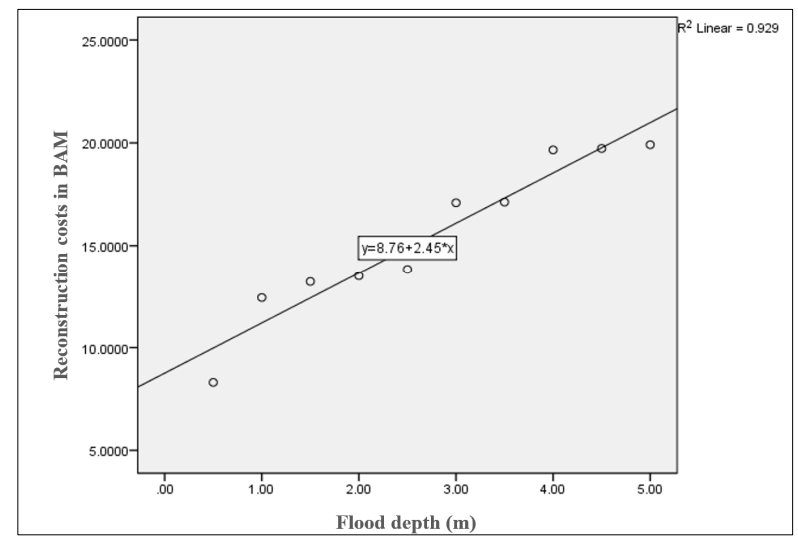

Figure 1: Damage function (curve) as a share of the assets value depending on the water depth in a representative building, excluding movables. (Source: Author.) 
In order to conduct interpolation and/or extrapolation of any damage value against the flood depth it is necessary to present the damage function in relation to the flood depth in a building without movables. Therefore, depending on the flood depth in a building without movables, the damage function in the Vrbas river basin reads as shown below

$$
y_{B P}=8,760+2,450 x,
$$

where $y_{B P}$ represents the reconstruction costs in BAM (1 EUR equals 1.95583 BAM) and $\mathcal{X}$ represents the flood depth, which is in fact the water depth in the building expressed in metres.

Presentation of the damage functions, utilizing linear function, was done due to the simplicity of the function, which also has high R-squared. As already mentioned, the data for damage functions were generated during implementation of the flood risk mitigation project in the Vrbas river basin for 13 municipalities/cities in this area. Those functions, among other things, are to be used by local and regional authorities addressing the flood risk mitigation issues. Every non-linear presentation of damage function could result in reluctance of authorities to use the damage functions and would return to non-selective and scientifically ungrounded flood risk mitigation approach.

\section{DAMAGE FUNCTION DEPENDING ON THE FLOOD DEPTH FOR BUILDINGS WITH MOVABLES}

Depending on the flood depth, the damage functions for representative buildings with movables was obtained based on the average value of assets in households per municipality within the Vrbas river basin, the reconstruction costs for all flood levels in buildings (from $0.5-5 \mathrm{~m}$ ) as well as the costs replacing movables (significant electrical appliances, furniture, agricultural equipment and other movables).

As previously mentioned, it was concluded that it is possible to establish three groups of municipalities presented through three damage functions. The following text explains these damage functions.

3.1 Damage function depending on the flood depth for buildings with movables in the City of Banja Luka

The average value of assets in the representative households in the City Banja Luka amounted to BAM 145,768 (EUR 74,530), including the civil engineering and electrical machinery value of buildings with movables. Table 2 and Fig. 2 were obtained based on an analysis of the reconstruction costs for all flood levels in the representative buildings (from 0.5-5 m).

To conduct interpolation and/or extrapolation of any damage value (as a share of the assets value) against the flood depth it is necessary to present the damage function. Therefore, depending on the flood depth in a building in the City of Banja Luka, the damage function reads as shown below

$$
y_{B L}=1.6 \cdot x+9.54
$$

where $y_{B L}$ represents the percentage of damage to the assets value for households in the City of Banja Luka and $x$ represents the flood depth (in fact the water depth in the building expressed in metres). 
Table 2: Reconstruction costs for representative buildings and the replacement of movables within the city Banja Luka and the percentage value of damage for representative buildings. (Source: Author.)

\begin{tabular}{|c|c|c|}
\hline $\begin{array}{l}\text { Water depth in } \\
\text { building }(\mathrm{x})\end{array}$ & $\begin{array}{l}\text { Cost of reconstruction and } \\
\text { replacement of movables }\end{array}$ & $\begin{array}{c}\% \text { of damage to the assets } \\
\text { value in households }\end{array}$ \\
\hline $0.5 \mathrm{~m}$ & 13,479 BAM $(6,892$ EUR $)$ & $9.25 \%$ \\
\hline $1.0 \mathrm{~m}$ & 17,425 BAM (8,909 EUR) & $11.95 \%$ \\
\hline $1.5 \mathrm{~m}$ & 18,173 BAM (9,292 EUR) & $12.47 \%$ \\
\hline $2.0 \mathrm{~m}$ & 18,440 BAM $(9,428$ EUR $)$ & $12.65 \%$ \\
\hline $2.5 \mathrm{~m}$ & 18,759 BAM (9,591 EUR) & $12.87 \%$ \\
\hline $3.0 \mathrm{~m}$ & 21,861 BAM (11,177 EUR) & $15.00 \%$ \\
\hline $3.5 \mathrm{~m}$ & 21,894 BAM (11,194 EUR) & $15.02 \%$ \\
\hline $4.0 \mathrm{~m}$ & 24,314 BAM (12,432 EUR) & $16.68 \%$ \\
\hline $4.5 \mathrm{~m}$ & 24,379 BAM (12,465 EUR) & $16.72 \%$ \\
\hline $5.0 \mathrm{~m}$ & 24,555 BAM (12,555 EUR) & $16.85 \%$ \\
\hline
\end{tabular}

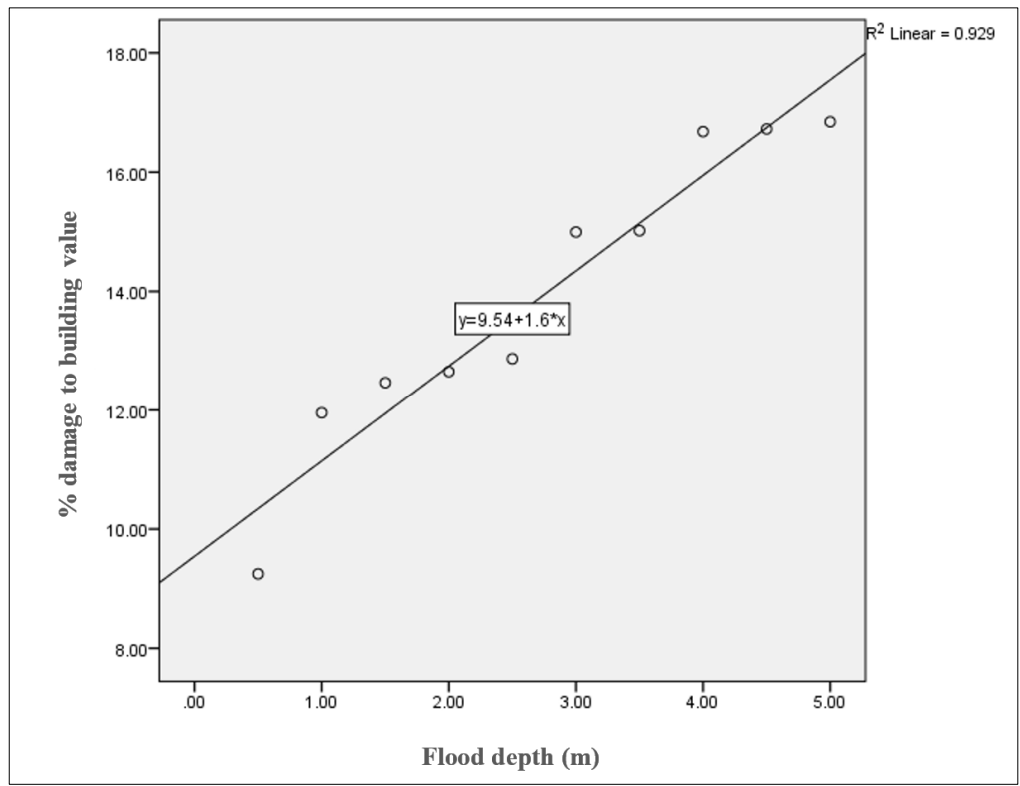

Figure 2: Damage function (curve) as a share of the assets value depending on the water depth in buildings in the city of Banja Luka. (Source: Author.)

3.2 Damage function depending on flood depth in building with movables in the municipalities of Gradiška, Jajce, Kotor Varoš, Laktaši and Srbac

The average value of assets in the households within the second group of municipalities totals 125,940 BAM (64,392 EUR). Based on the analysis of the reconstruction costs at all flooded levels of building (from $0.5-5 \mathrm{~m}$ ) as well as estimated amount needed for replacement of movables affected by floods, Table 3 and Fig. 3 are obtained. 
Table 3: Reconstruction costs, replacement of movables and a percentage of the damage value for the second group of municipalities. (Source: Author.)

\begin{tabular}{|c|c|c|}
\hline $\begin{array}{l}\text { Water depth in } \\
\text { building }(\mathrm{x})\end{array}$ & $\begin{array}{l}\text { Cost of reconstruction and the } \\
\text { replacement of movables }\end{array}$ & $\begin{array}{c}\% \text { of damage to the assets } \\
\text { value in households }\end{array}$ \\
\hline $0.5 \mathrm{~m}$ & 15,243 BAM (7,794 EUR) & $12.10 \%$ \\
\hline $1.0 \mathrm{~m}$ & 19,189 BAM $(9,811$ EUR) & $15.24 \%$ \\
\hline $1.5 \mathrm{~m}$ & 19,937 BAM (10,194 EUR) & $15.83 \%$ \\
\hline $2.0 \mathrm{~m}$ & 20,204 BAM (10,330 EUR) & $16.04 \%$ \\
\hline $2.5 \mathrm{~m}$ & 20,523 BAM (10,493 EUR) & $16.30 \%$ \\
\hline $3.0 \mathrm{~m}$ & 23,625 BAM (12,079 EUR) & $18.76 \%$ \\
\hline $3.5 \mathrm{~m}$ & 23,658 BAM (12,096 EUR) & $18.79 \%$ \\
\hline $4.0 \mathrm{~m}$ & 26,078 BAM (13,333 EUR) & $20.71 \%$ \\
\hline $4.5 \mathrm{~m}$ & 26,143 BAM (13,367 EUR) & $20.76 \%$ \\
\hline $5.0 \mathrm{~m}$ & 26,319 BAM (13,457 EUR) & $20.90 \%$ \\
\hline
\end{tabular}

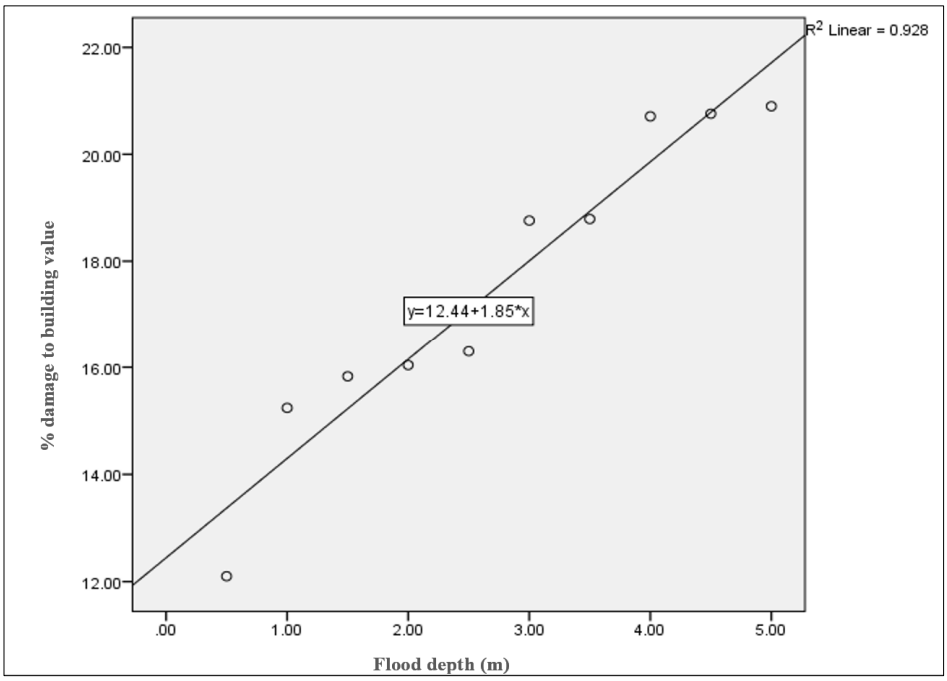

Figure 3: Damage function (curve) as a share of the assets value depending on the water depth in buildings in the municipalities of Gradiška, Jajce, Kotor Varoš, Laktaši and Srbac. (Source: Author.)

To conduct interpolation and/or extrapolation of any damage value (as a share of the assets value) against the flood depth it is necessary to present the damage function. Therefore, the damage function, depending on the flood depth in buildings in the municipalities of Gradiška, Jajce, Kotor Varoš, Laktaši and Srbac reads as shown below

$$
y_{D G}=1.85 \cdot x+12.44,
$$

where $y_{D G}$ represents the percentage of damage to the assets value in the municipalities of Gradiška, Jajce, Kotor Varoš, Laktaši and Srbac and $x$ represents the flood depth (in fact the water depth in the building expressed in metres). 
3.3 Damage function depending on the flood depth in buildings with movables in the municipalities of Bugojno, Čelinac, Donji Vakuf, Gornji Vakuf, Jezero, Šipovo and Mrkonjić Grad

The average value of assets in the households within the third group of municipalities amounted to BAM 83,097 (42,487 EUR), including the civil engineering and electrical machinery value of buildings with movables. Table 4 and Fig. 4 are based on an analysis of the reconstruction costs for all flood levels in these buildings (from $0.5-5 \mathrm{~m}$ ) as well as the estimated amount needed to replace movables affected by the floods.

Table 4: Reconstruction costs, replacement of movables and a percentage of the damage value for the third group of municipalities. (Source: Author.)

\begin{tabular}{|c|c|c|}
\hline $\begin{array}{l}\text { Water depth in } \\
\text { building }(\mathrm{x})\end{array}$ & $\begin{array}{l}\text { Cost of reconstruction and the } \\
\text { replacement of movables }\end{array}$ & $\begin{array}{c}\% \text { of damage to the assets } \\
\text { value of households }\end{array}$ \\
\hline $0.5 \mathrm{~m}$ & 15,040 BAM (7,690 EUR) & $18.10 \%$ \\
\hline $1.0 \mathrm{~m}$ & 18,987 BAM $(9,708$ EUR $)$ & $22.85 \%$ \\
\hline $1.5 \mathrm{~m}$ & 19,735 BAM $(10,090$ EUR $)$ & $23.75 \%$ \\
\hline $2.0 \mathrm{~m}$ & 20,002 BAM (10,227 EUR) & $24.07 \%$ \\
\hline $2.5 \mathrm{~m}$ & 20,321 BAM (10,390 EUR) & $24.45 \%$ \\
\hline $3.0 \mathrm{~m}$ & 23,423 BAM (11976 EUR) & $28.19 \%$ \\
\hline $3.5 \mathrm{~m}$ & 23,456 BAM (11,993 EUR) & $28.23 \%$ \\
\hline $4.0 \mathrm{~m}$ & 25,876 BAM $(13,230$ EUR) & $31.14 \%$ \\
\hline $4.5 \mathrm{~m}$ & 25,940 BAM (13,263 EUR) & $31.22 \%$ \\
\hline $5.0 \mathrm{~m}$ & 26,117 BAM (13,353 EUR) & $31.43 \%$ \\
\hline
\end{tabular}

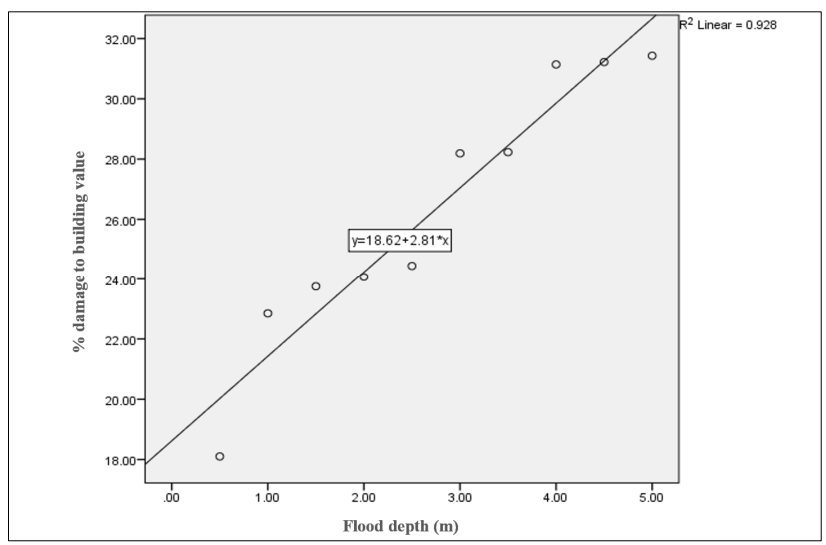

Figure 4: Damage function (curve) as a share of the assets value depending on the water depth in buildings for the third group of municipalities. (Source: Author.)

To conduct interpolation and/or extrapolation of any damage value (as a share of the assets value) against the flood depth it is necessary to present the damage function. Therefore, the damage function depending on the flood depth in a building in the municipalities of Bugojno, Čelinac, Donji Vakuf, Gornji Vakuf, Jezero, Šipovo and Mrkonjić Grad reads shown below 


$$
y_{T G}=2.81 x+18.62
$$

where $y_{T G}$ represents the percentage of damage to the assets value in the municipalities of Bugojno, Čelinac, Donji Vakuf, Gornji Vakuf, Jezero, Šipovo and Mrkonjić Grad and $x$ represents the flood depth (in fact the water depth in the building expressed in metres).

\subsection{A comparison between damage functions in the Vrbas river basin and other regions}

So far, there is no generally accepted methodology for the construction of these functions because they reflect local conditions and therefore vary from country to country. For comparison purposes the functions of potential damage to the rivers Rhine and Elba in Germany [6] and a the case study of the City of Palermo in Italy [7] and the Municipality of Moschato in Greece [8] as well as guidelines on damage functions for different types of residential buildings that was developed by the US Army Corps of Engineers [9] were considered.

After considering the damage functions for the above-mentioned research and comparing them with the damage functions in the Vrbas river basin, it was possible to conclude the following for a flood-depth of $1 \mathrm{~m}$, as shown in Fig. 5:

- The damage values for the City of Banja Luka (Vrbas river basin) and the region around the River Rhine are similar at around $11 \%$ of the assets value.

- The damage values for the municipalities of Gradiška, Jajce, Kotor Varoš, Laktaši and Srbac (Vrbas river basin) are similar to the damage functions used in the study by the US Army Corps of Engineers at around 14\% of the assets value.

- The damage values for the municipalities of Bugojno, Čelinac, Donji Vakuf, Gornji Vakuf, Jezero, Šipovo and Mrkonjić Grad (Vrbas river basin) and the region around the River Elba are similar at around $20 \%$ of the assets value.

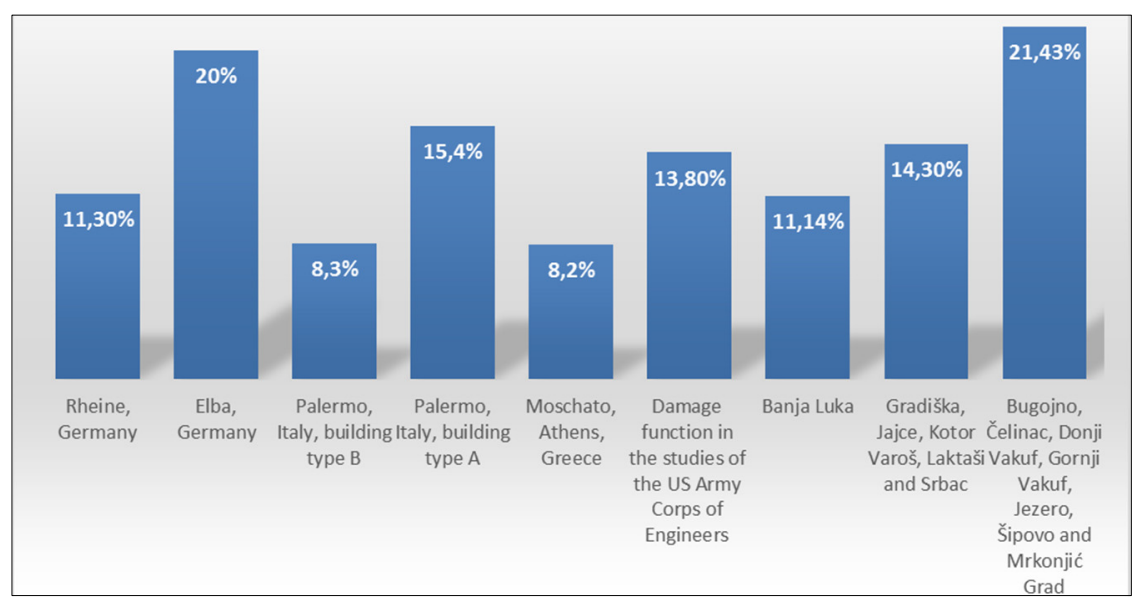

Figure 5: Comparative values as a damage share of the assets value of households for a flood depth of $1 \mathrm{~m}$. (Source: Author.) 


\section{DAMAGE IN THE AGRICULTURAL SECTOR}

Damage to agriculture was assessed as the combined damage caused in the flood area for the following agricultural crops: wheat, corn, barley, potato, apple, plum and pear. These are the most represented crops in the target area. They are also the crops for which the statistic institutes in BH collect, analyse and publish data on the planted surface, the yield and similar aspects at the municipal level. The authors of the methodology were aware that there are other crops in the target basin (farming crops, fruits and vegetables), but there are no official records about them per municipalities, so that they are not included in the calculation. The damage to the agricultural crops mentioned above resulted from yield reduction caused by flood, which is presented per hectare in BAM/EUR.

The format of Table 5 was used to calculate the reduction in yield attributed to flooding in each municipality located in the flood area. The reason for presenting data at the municipal level is the significant differences in agricultural development in the various municipalities. For example, Table 5 was used for the City of Banja Luka.

The following table of flood probability was calculated based on the annual maximum flow $\left(\mathrm{m}^{3} / \mathrm{s}\right)$ as per the calculation of the chief technical consultant within the project "Integrating Climate Changes and Reducing the Risk of Flooding in the Vrbas River Basin".

The maximum flood damage (\%) compared to the monthly yield, in fact the decrease in yield in percentage compared to the anticipated values, was taken from the second technical report for the agriculture sector in the Vrbas river basin [10]. For the above-mentioned agricultural crops within the category of winter grains (wheat and barley), the maximum flood damage, in fact the decrease in yield in percentage compared to the anticipated value, are attributed to excessive land humidity for a period in excess of 15 days. The same principle applies to the data for periods of excessive humidity for agricultural crops and therefore the period of 15 days was used for corn, 11 days for potato, while 15 days was also used for fruits. Therefore, the results present the maximum damage to agriculture under large water floods. These two values provide weighted loss in percentage calculated as the sum of the flood probability product and the monthly percentage of damage to yields.

The average yield presented as value $t / h a$ is calculated as a 10-year average of yield [11]. Besides, net revenues per crop type are equal to the average price in BAM/kg minus production costs in BAM $/ \mathrm{kg}$ [12]. The prices of agricultural crops represent the 10 -year average [11]. Losses in agricultural crops at the municipal level are presented in BAM/ha and are calculated as a product of weighed loss in percentages, the average yield of the agricultural crops and average net revenue. Based on this equation, the expected flood losses are obtained in BAM per ha of land for certain types of crops.

If there was a cadastre of agricultural crops in $\mathrm{BH}$ providing information on the type of crops grown in certain agriculture fields then the values from the next table could have been used to multiply the size of the corps under water by the losses per ha of certain crop type in order to obtain losses per crop and per municipality. However, as we did not know which crops were located in the flood areas, we applied an alternative approach. Geographic information system software was applied to the total flooded surface per municipality. Part of those total flooded surfaces belonged to the above-mentioned agricultural crops. The total land surface under the above-mentioned crops within the entire municipality was then compared to the total size of the municipality. In this way, the share/percentage of land surface for each crop per municipality was obtained and then copied to the flooded areas per municipality. In this way, the sizes of land under crops presented in ha within the flooded area was obtained and calculated. 


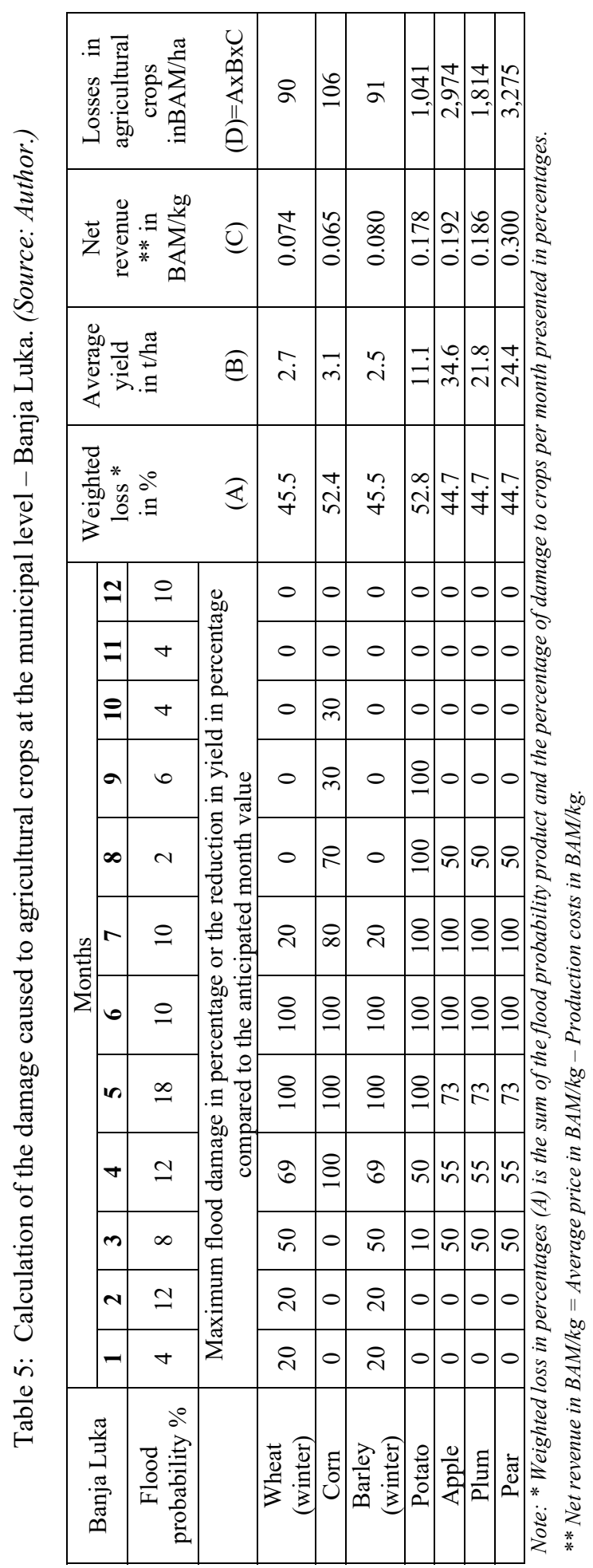




\section{CONCLUSION}

Flood damage functions have been created for the first time in Bosnia and Herzegovina with a purpose to demonstrate a level of damage caused by floods to household assets and agricultural sector in Vrbas River Basin. These functions have been used to calculate potential flood damages and calculation results have been used (1) as a basis for cost-benefit analysis of flood protection measures; (2) in order to determine what flood risk reduction measures will achieve maximum financial benefits; and (3) to develop insurance products. Obtained values have shown similarities with damage functions developed for other relevant flood damage studies in Europe.

Potential damages have been assessed for residential and agricultural sectors. Hydrological and hydraulic models developed for Vrbas river basin with precise flood depth values for 500-year waters have been used as a base for these calculations. These flood depths and household damage functions were used to determine the average percentage of damage for $1 / 500$ floods. Based on that, the absolute value of assessed damage amounts to approximately BAM 90 million (EUR 46 million). The total average damage value for $1 / 500$ floods for agricultural sector was assessed at approximately BAM 1.4 million (EUR 0.7 million).

The above-mentioned assessments of damage for residential buildings and agriculture sector comply with actual damages. According to the report of the Ministry of Spatial Planning, Construction and Ecology, the floods from 2014., which had the characters of $1 / 500$ floods caused the damage of 130 million BAM (EUR 66 million) [13]. In addition to damages in residential and agriculture sectors, this amount also includes damages in business and public sectors as well.

\section{REFERENCES}

[1] Smith, D.I., Flood damage estimation - A review of urban stage damage curves and loss functions. Water SA, 20(3), pp. 231-238, 1994.

[2] Merz, B. et al., Estimation uncertainty of direct monetary flood damage to buildings. Natural Hazards and Earth System Sciences - Landslide and flood hazards assessment, 4, pp. 153-163, 2004.

[3] Penning-Rowsell, E. et al., The Benefits of Flood and Coastal Risk Management: A Handbook of Assessment Techniques, Middlesex University Press: London, 2005.

[4] Messner, F. et al., Evaluating Flood Damages: Guidance and Recommendations on Principles and Methods, HR Wallingford: UK, pp. 26, 2007.

[5] Davis, S. \& Skaggs, L., Catalogue of Residential Depth-Damage Functions, U.S. Army Corps of Engineers, Institute for Water Resources, pp. 2, 1992.

[6] Jovanović, M., Todorović, A. \& Rodić, M., Flood risk mapping. Vodoprivreda, 41(1-3), pp. 31-45, 2009.

[7] Oliveri, E. \& Santoro, M., Estimation of urban structural flood damages: The case study of Palermo. Urban Water, 2, pp. 223-234, 2000.

[8] Pistrika, A., Tsakiris, G. \& Nalbantis, I., Flood depth-damage functions for built environment. Environmental Processes, 1, pp. 553-572, 2014.

[9] U.S. Army Corps of Engineers, Generic Depth-Damage Relationships for Residential Structures with Basements, Economic Guidance Memorandum (EGM) 04-01, 2003.

[10] Ćustović, H., Second technical report for agriculture sector in the Vrbas river basin, 2017.

[11] Entity Statistics Institutes, Annual statistic reports, 2007-2017. 
[12] Economics of primary agricultural production and agricultural policy measures in the Federation of $B \& H$, The Faculty of Agriculture and Food Sciences, University of Sarajevo, Bosnia and Herzegovina, 2010.

[13] Nezavisne novine. www.nezavisne.com/novosti/bih/Golic-Sliv-Vrbasa-najuredjenijiu-BiH/565278. Accessed on: 7 Feb. 2020. 